\title{
Lipocalin 2 as a clinical significance in rheumatoid arthritis
}

\author{
ARIF GULKESEN ${ }^{1}$, GURKAN AKGOL', AHMET K. POYRAZ², SULEYMAN AYDIN ${ }^{3}$, \\ AFFAN DENK ${ }^{4}$, TULAY YILDIRIM ${ }^{5}$, ARZU KAYA ${ }^{l}$ \\ ${ }^{1}$ Department of Physical Medicine and Rehabilitation, Faculty of Medicine, Firat University, Elazig, Turkey \\ ${ }^{2}$ Department of Radiology, Faculty of Medicine, Firat University, Elazig, Turkey \\ ${ }^{3}$ Department of Biochemistry and Clinical Biochemistry (Firat Hormones Research Group), School of Medicine, Elazig, Turkey \\ ${ }^{4}$ Department of Infectious Diseases and Clinical Microbiology, Faculty of Medicine, Firat University, Elazig, Turkey \\ ${ }_{5}^{5}$ Department of Physical Medicine and Rehabilitation, Faculty of Medicine, Inonu University, Malatya, Turkey
}

\begin{abstract}
Aim of the study: In this study, serum lipokalin 2 (LCN-2) levels and its clinical and radiological significance in patients with rheumatoid arthritis was evaluated.

Material and methods: The study enrolled 37 patients with RA and 34 healthy controls. Serum LCN-2 level was measured using ELISA method. Patients with DAS 28 scores $\leq 3.2$, and $>3.2$ were allocated into lower and high/moderate disease activity groups, respectively. Additionally patients were divided into 2 groups as early $R A$ (disease duration $\leq 2$ years) and established $R A$ (duration of the disease $\geq 2$ years). Functional disability was evaluated using Health Assessment Questionnaire (HAQ). Radiographs were scored using the modified Larsen score.

Results: Serum LCN-2 $(p=0.029)$ levels were significantly higher in patients with RA than in the controls. Serum LCN-2 level did not correlate with laboratory and clinical parameters of disease activity like erythrocyte sedimentation rate (ESR), C-reactive protein (CRP), DAS 28, Health Assessment Questionnaire Score (HAQ) and Nottingham Health Profile (NHP). Similarly, any correlation could not be found between structural joint damage and serum LCN2 levels.

Conclusions: These results indicate that serum LCN-2 levels may be used as an indicator for structural damage like erosions in the early stage of the disease but do not able to be used to monitor disease activity.
\end{abstract}

Key words: rheumatoid arthritis, disease activity, lipokalin 2, modified Larsen score.

(Cent Eur J Immunol 2017; 42 (3): 269-273)

Rheumatoid arthritis (RA) is a chronic systemic autoimmune inflammatory disease characterized by symmetrical synovitis, progressive joint damage, pain, fatigue, disability and increased levels of proinflammatory cytokines such as (interleukin 1 [IL-1] and interleukin 6 [IL-6]). Although the exact etiology of this disease is not known, recent studies show that lipocalin 2 (LCN-2) is a known inflammatory biomarker that has a positive correlation with body mass index and various metabolic syndromes [1,2].

Lipocalin 2, also known as neutrophilgelatinase-associated lipocalin, is a glucoprotein that was first isolated from the renal cells of mice and those of humans. LCN-2 is a $25-\mathrm{kD}$ a protein having monomeric, homodimeric, and heterodimeric forms. It is mostly synthesized from the adipose tissue and hepatic cells [3]. After further research, LCN-2 was observed to be expressed from various other cells. For example, during inflammation it is synthesized from epithelial cells [4-6]. LCN-2 plays a role in various cellular events, including immune response, differentiation, and tumorogenes [6]. LCN-2 is a chemokine isolated from fatty tissue and its structure is similar to that of the proteins that cover fatty acids. With increased $L C N-2$ gene expression in the fatty tissue and livers of the genetically obese animals and decreased $L C N-2$ gene expression in obese animals that are given anti-diabetic drugs, the idea that this protein is a proinflammatory agent is strengthened [7]. Early diagnosis of rheumatoid arthritis is important for preventing joint damage via treatment. For patients having typical symptoms, the disease could be easily diagnosed, often in the first year of disease onset. For many patients with atypical symptoms, it could take more time to diagnose. Therefore, specific and sensitive serological tests are required for diagnosis.

Correspondence: Gurkan Akgol, Department of Physical Medicine and Rehabilitation, Faculty of Medicine, Firat University, 23119 Elazig, Turkey, e-mail: drgurkanakgol@gmail.com Submitted: 17.03.2017, Accepted: 30.05.2016 
This study aimed to investigate the association between LCN-2 levels and disease severity as measured by disease activity, functional capacity, and structural damage evaluated by using conventional radiography.

\section{Material and methods}

Patients who met the American College of Rheumatology (ACR) classification criteria for RA and were who followed up for at least one year were enrolled [8]. Patients with a diagnosis of autoimmune diseases other than RA, acute and chronic infections, malignancies, serious pulmonary, hepatic, or renal or endocrine diseases; those who smoked; those who had hypertension (arterial blood pressure $\geq 140 / 90 \mathrm{~mm} \mathrm{Hg}$ or on anti-hypertensive drugs), hypercholesterolemia, or were pregnant with a body mass index $(\mathrm{BMI})>30 \mathrm{~kg} / \mathrm{m}^{2}$; and those aged $<20$ years or $>70$ years were excluded from the study. Age and sex-matched 30 healthy controls were included in the study. The study was approved by the local ethics committee and informed consent was obtained from all participants.

\section{Clinical evaluations}

Severity of pain, fatigue, and patient and physicians global assessment of disease activity were assessed on a Visual Analogue Scale (VAS). Duration of morning stiffness was noted in minutes. Disease activity was evaluated using Disease Activity Scores-28 (DAS-28) [9]. Patients with DAS 28 score of $\leq 3.2$ were evaluated as having lower disease activity, while DAS 28 score of $>3.2$ indicated patients with high/moderate disease activity [10]. Additionally, patients were divided into 2 groups based on the disease duration: early RA (disease duration $\leq 2$ years) and established RA (duration of the disease $\geq 2$ years). Functional disability was evaluated using the "Health Assessment Questionnaire" (HAQ) and Nottingham Health Profile (NHP) [11, 12].

\section{Laboratory evaluations}

Routine laboratory test results were recorded (erythrocyte sedimentation rate [ESR], blood chemistry, whole blood cell count, and urinalysis). Rheumatoid factor (RF) Anti-Cyclic citrullinated peptide (Anti-CCP and C-reactive protein (CRP) levels were measured using nephelometric methods.

\section{Lipocalin-2 assay}

Venous blood samples were drawn from the patients and healthy controls as described previously [13] and centrifuged at $4000 \mathrm{rpm}$ for 10 minutes. The sera were kept at $-20^{\circ} \mathrm{C}$ until the analysis. Serum LCN-2 was studied with ELISA method human neutrophil gelatinase associated lipocalin (NGAL) in accordance with the user manual of the commercial kit (Awareness Technology, Inc. Palm City,
Florida, USA). The minimum detection limit of lipocalin-2 was $12 \mathrm{ng} / \mathrm{ml}$, the intra-assay variation and the interassay variation being $<10 \%$. The results are presented in $\mathrm{ng} /$ ml unit.

\section{Radiological evaluation}

Standard, plain hand radiographs of the patients taken within the last 6 months were examined. Structural damage in the hand radiographs were evaluated by the radiologist who was blinded to the patients' clinical and laboratory data. Radiographs were scored using the "Modified Larsen Score". In this scoring system, 24 areas in both hands were scored (each area 0 to 5 points, total score $0-120$ points) [14].

\section{Statistical evaluation}

Statistical analysis of the study was performed using "Statistical Package Program for Social Sciences" (IBM SPSS Statistics for Windows, Version 20.0. Armonk, NY: IBM Corp.). The results of the study were evaluated using parametric and nonparametric statistical methods for data with normal and non-normal distribution, respectively. Intergroup comparisons were performed using independent groups T test for parametric and Mann-Whitney U tests for non-parametric values. Correlations between parameters were evaluated using Spearman correlation coefficient. In statistical evaluations, $\mathrm{p}<0.05$ was accepted as the level of significance. The results were expressed as mean \pm standard deviation (SD).

\section{Results}

A total of 37 patients ( 29 women and 8 men) were included. Patients with RA and controls were age matched $(\mathrm{P}=0.086)$. Mean disease duration was $12.81 \pm 6.75$ years. Twenty-eight $(75 \%)$ patients were RF positive and 30 patients $(81 \%)$ were CCP positive. There were 17 patients (45.9\%) taking DMARD; 14 (37.8\%) patients using one or more DMARD treatment together with methotrexate; 3 patients $(8,1 \%)$ using DMARD treatment without methotrexate; 2 patients $(5.4 \%)$ using exclusively biological agent; and 18 patients $(48.6 \%)$ using a biological agent with methotrexate. There was not a meaningful difference between serum LCN-2 levels of RA patients with biological agents $(803.07 \pm 447.13 \mathrm{ng} / \mathrm{ml})$ and serum LCN-2 levels of patients using DMARD $(750.74 \pm 563.55 \mathrm{ng} / \mathrm{ml})$ $(p=0.587)$.

In the RA group, average serum LCN-2 level was found to be $803.80 \pm 508.62 \mathrm{ng} / \mathrm{ml}$. Serum LCN-2 levels of male patients in RA group were found as $(695.12 \pm 240.73$ $\mathrm{ng} / \mathrm{ml})$, and serum LCN-2 levels of female patients were found as $(830.84 \pm 560.26 \mathrm{ng} / \mathrm{ml})$. A meaningful difference wasn't found between male and female genders ( $p=$ 0.502). In control group, serum LCN-2 level was 597.66 
Table 1. Comparison of demographic, clinical and laboratory parameters between RA patients and healthy controls

\begin{tabular}{|c|c|c|c|}
\hline & $\begin{array}{c}\text { Rheumatoid } \\
\text { arthritis }(n=37)\end{array}$ & $\begin{array}{l}\text { Controls } \\
(n=34)\end{array}$ & $p$ \\
\hline Age (years) & $48.95 \pm 7.63$ & $45.76 \pm 7.72$ & 0.086 \\
\hline Female/Male & $29 / 8$ & $17 / 17$ & 0.012 \\
\hline BMI & $28.55 \pm 4.46$ & $29.08 \pm 4.20$ & 0.608 \\
\hline $\begin{array}{l}\text { Duration of the } \\
\text { disease (years) }\end{array}$ & $12.81 \pm 6.75$ & & \\
\hline $\begin{array}{l}\text { Morning stiffness } \\
\text { (min.) }\end{array}$ & $111.62 \pm 79.14$ & & \\
\hline Pain (0-10 cm VAS) & $5.81 \pm 1.72$ & & \\
\hline $\begin{array}{l}\text { Fatigue } \\
(0-10 \mathrm{~cm} \text { VAS })\end{array}$ & $5.86 \pm 1.58$ & & \\
\hline $\begin{array}{l}\text { Patients global } \\
(0-10 \mathrm{~cm} \text { VAS })\end{array}$ & $5.92 \pm 1.55$ & & \\
\hline $\begin{array}{l}\text { Physicians global } \\
(0-10 \mathrm{~cm} \text { VAS })\end{array}$ & $5.86 \pm 1.65$ & & \\
\hline $\begin{array}{l}\text { Number of the } \\
\text { swollen joints }(0-28)\end{array}$ & $1.70 \pm 2.22$ & & \\
\hline $\begin{array}{l}\text { Number of the tender } \\
\text { joints }(0-28)\end{array}$ & $7.08 \pm 4.84$ & & \\
\hline $\begin{array}{l}\text { Erythrocyte } \\
\text { sedimentation rate } \\
(\mathrm{mm} / \mathrm{h})\end{array}$ & $27.76 \pm 15.71$ & $9.85 \pm 8.91$ & 0.001 \\
\hline $\begin{array}{l}\text { C reactive protein } \\
(\mathrm{g} / \mathrm{dl})\end{array}$ & $19.78 \pm 34.56$ & $5.04 \pm 3.77$ & 0.001 \\
\hline $\begin{array}{l}\text { Rheumatoid factor } \\
(\mathrm{IU} / \mathrm{ml})\end{array}$ & $99.10 \pm 126.30$ & $10.67 \pm 0.61$ & 0.001 \\
\hline $\begin{array}{l}\text { Anti-Cyclic } \\
\text { citrullinated peptide } \\
(\mathrm{IU} / \mathrm{ml})\end{array}$ & $285.68 \pm 303.82$ & & \\
\hline $\begin{array}{l}\text { Serum LCN-2 } \\
(\mathrm{ng} / \mathrm{ml})\end{array}$ & $803.80 \pm 508.62$ & $\begin{array}{c}597.66 \\
\pm 182.33\end{array}$ & 0.029 \\
\hline
\end{tabular}

\begin{tabular}{lccc}
\hline $\begin{array}{l}\text { Disease Activity } \\
\text { Score 28 }\end{array}$ & $4.27 \pm 1.29$ & & \\
\hline $\begin{array}{l}\text { Health Assessment } \\
\text { Questionnaire 20 } \\
(0-3)\end{array}$ & $31.32 \pm 9.11$ & $3.82 \pm 5.99$ & 0.001 \\
\hline $\begin{array}{l}\text { Modified Larsen } \\
\text { Score (0-120) }\end{array}$ & $56.11 \pm 31.20$ & & \\
\hline VAS - Visual Analogue Scale, LCN-2 - Lipocalin 2 &
\end{tabular}

$\pm 182.33 \mathrm{ng} / \mathrm{ml}$. Serum LCN-2 levels of male control participants were found as $(578.87 \pm 197.12 \mathrm{ng} / \mathrm{ml})$, and serum LCN-2 levels of female control participants were found as $(616.67 \pm 170.23 \mathrm{ng} / \mathrm{ml})$. A meaningful difference wasn't found between male and female control group participants
Table 2. Comparison of patients between high/moderate (DAS $28>3.2$ ) and low disease activity (DAS $28 \leq 3.2$ )

\begin{tabular}{lccc}
\hline & $\begin{array}{c}\text { High/moderate } \\
\text { disease activity } \\
(\boldsymbol{n}=\mathbf{2 7})\end{array}$ & $\begin{array}{c}\text { Low disease } \\
\text { activity }(\boldsymbol{n}=\mathbf{1 0})\end{array}$ & $\boldsymbol{p}$ \\
\hline Age (years) & $48.11 \pm 8.38$ & $51.20 \pm 4.70$ & 0.281 \\
\hline Female/Male & $20 / 7$ & $9 / 1$ & 0.296 \\
\hline $\begin{array}{l}\text { Duration of the } \\
\text { disease (years) }\end{array}$ & $11.63 \pm 6.49$ & $16.00 \pm 6.73$ & 0.080 \\
\hline $\begin{array}{l}\text { Rheumatoid } \\
\text { factor (IU/ml) }\end{array}$ & $118.53 \pm 140.31$ & $46.64 \pm 52.35$ & 0.126 \\
\hline $\begin{array}{l}\text { Anti-cyclic } \\
\text { citrullinated } \\
\text { peptide (IU/ml) }\end{array}$ & $275.74 .94 \pm 289.41$ & $312.52 \pm 355.19$ & 0.749 \\
\hline $\begin{array}{l}\text { ESR (mm/h) } \\
\text { (n) }\end{array}$ & $30.56 \pm 16.24$ & $20.20 \pm 11.78$ & 0.075 \\
\hline $\begin{array}{l}\text { C-reactive } \\
\text { protein (g/d) }\end{array}$ & $25.36 \pm 39.12$ & $4.73 \pm 3.23$ & 0.108 \\
\hline $\begin{array}{l}\text { Serum LCN-2 } \\
\text { (ng/ml) }\end{array}$ & $821.38 \pm 536.13$ & $756.33 \pm 448.30$ & 0.735 \\
\hline ESR - erythrocyte sedimentation rate, LCN-2 & & \\
\hline
\end{tabular}

ESR - erythrocyte sedimentation rate, $L C N-2$ - lipocalin 2

$(p=0.554)$. Serum LCN-2 $(p=0.029)$ levels were significantly higher in patients with RA than in the controls (Table 1). Serum LCN-2 ( $p=0.735)$ levels were similar between moderate/high and low disease activity RA subgroups (Table 2).

There was not a meaningful difference between serum $\mathrm{LCN}-2$ levels of $\mathrm{RF}(+)$ patients $(847.51 \pm 540.49 \mathrm{ng} /$ $\mathrm{ml})$ and serum LCN-2 levels of RF(-) patients (620.89 $\pm 344.53 \mathrm{ng} / \mathrm{ml})(p=0.197)$ in the same way, there was not a meaningful difference between serum LCN-2 levels of anti-CCP(+) patients $(816.70 \pm 544.82 \mathrm{ng} / \mathrm{ml})$ and serum $\mathrm{LCN}-2$ levels of anti-CCP(-) patients $(667.99 \pm 307.44 \mathrm{ng} /$ ml) $(p=0.950)$.

In the rheumatoid arthritis group, any correlation could not be determined between serum LCN-2 levels and age, positive RF, positive anti-CCP, duration of disease, and ESR or CRP levels. In the RA and control groups, no correlations were found between serum LCN-2 level and BMI (respectively $r=0.294, p=0.077$ and $r=-0.153$, $p=387$ ). Serum LCN-2 levels did not correlate with any other laboratory or clinical parameters of disease activity. Serum RF and CCP levels did not correlate with LCN2 levels. However, a significant correlation was detected between modified Larsen scores and serum LCN-2 levels $(r=0.395, p=0.015)$. There was a statistical meaningful difference between serum LCN-2 levels of RA patients with modified Larsen score $>40(991.87 \pm 625.66 \mathrm{ng} / \mathrm{ml})$ and serum LCN-2 levels of RA patients with modified Larsen score $\leq 40(605.79 \pm 266.74 \mathrm{ng} / \mathrm{ml})(p=0.039)$. 


\section{Discussion}

Our study reveals that LCN-2 levels are higher in patients with RA than in healthy individuals, and is associated with joint damage assessed by modified Larsen scores.

Previous studies have indicated the role of neutrophil dysfunction in the etiopathogenesis of RA [15]. Anticytokine treatments can control the progression of the disease; however, in case of discontinuation of these medications, the disease is exacerbated because of persistence of neutrophil infiltration into the synovia [16]. Therefore, treatment strategies directed at effector cells playing a crucial role in the etiopathogenesis of RA have been established.

Adipose tissue-derived adipokines and cytokines play important roles in energy homeostasis, inflammation, and insulin resistance [7]. Tissue distribution and expression of LCN-2 in neutrophils, bone marrow, and tissues exposed to microorganisms, such as the trachea, lung, stomach, salivary gland, and colon [17] indicate its involvement in inflammatory responses. In neutrophils, LCN-2 secretion is highly regulated by infection and the activation of inflammation [18]; lipopolysaccharide (LPS) and TNF- $\alpha$ are the two strong inducers of LCN-2 production.

In our study, LCN-2 levels are higher in patients with RA than in healthy individuals. Similarly, Katano et al. [15] found in their study that serum LCN-2 levels were higher in RA patients than in osteoarthritis patients and healthy controls. However, contrary results were also reported [19].

In our literature survey, we did not encounter any study that assessed the association between LCN-2 levels and disease activity in patients with RA. Based on our findings, we can assume that serum LCN-2 levels in RA patients are not directly correlated with inflammatory activation.

In our study, a significant correlation was found between serum LCN-2 levels and modified Larsen scores, which demonstrates a possible association with joint damage. To the best of our knowledge, this association has not been assessed previously.

We found no differences in terms of serum LCN2 levels among RA patients who applied different treatment protocols. The data is highly limited regarding potential interaction between LCN-2 and anti-rheumatic drugs, which warrants further research.

The main limitation of our study is its cross-sectional design and relatively small sample size. In this study, determining only LCN-2 without concerning other adipokineses is another limitation of the study. On the other hand, our wide exclusion criteria prevented us from adding more patients to the study.

In conclusion, our study demonstrated increased serum levels of LCN-2 in patients with RA compared to that in healthy controls. We did not demonstrate an association between disease activity and LCN-2; however, we showed a relationship between LCN-2 and joint damage. Our find- ings indicate the possible role of LCN-2 in the RA disease process and possibly joint damage.

The authors declare no conflict of interest.

\section{References}

1. Smolen JS, Aletaha D, Koeller M, et al. (2007): New therapies for treatment of rheumatoid arthritis. Lancet 370: 18611874.

2. Wang Y, Lam KS, Kraegen EW, et al. (2007): Lipocalin-2 is an inflammatory marker closely associated with obesity, insulin resistance, an hyperglycemia in humans. Clin Chem 53: 34-41.

3. Kjeldsen L, Johnsen AH, Sengelov H, et al. (1993): Isolation and primary structure of NGAK, a novel protein associated with human neutrophil gelatinase. J Biol Chem 268: 14251432.

4. Kjeldsen L, Cowland JB, Borregaard N (2000): Human neutrophil gelatinase- associated lipocalin and homologous proteins in rat and mouse. Biochim Biophys Acta 1482: 272-283.

5. Friedl A, Stoesz SP, Buckley P, et al. (1999): Neutrophil gelatinase- associated lipocalin in normal and neoplastic human tissues. Cell type-specific pattern of expression. Histochem J 31: 433-441.

6. Devireddy LR, Teodoro JG, Richard FA, et al. (2001): Induction of apoptosis by a secreted lipocalin that is transcriptionally regulated by IL-3 deprivation. Science 293: 829-834.

7. Zhang J, Wu Y, Zhang Y, et al. (2008): The role of lipocalin 2 in the regulation of inflammation in adipocytes and macrophages. Mol Endocrinol 22: 1416-1426.

8. Arnett FC, Edworthy SM, Bloch DA, et al. (1988): American Rheumatism Association 1987 revised criteria for the classification of rheumatoid arthritis. Arthritis Rheum 31: 315-324.

9. Prevoo MLL, van't Hof MA, Kuper HH, et al. (1995): Modified disease activity scores that include twenty-eight-joint counts. Development and validation in a prospective longitudinal study of patients with rheumatoid arthritis. Arthritis Rheum 38: 44-8.

10. Fransen J, Stucki G, van Riel PL (2003): Rheumatoid arthritis measures: Disease Activity Score (DAS), Disease Activity Score-28 (DAS28), Rapid Assessment of Disease Activity in Rheumatology (RADAR), and Rheumatoid Arthritis Disease Activity Index (RADAI). Arthritis Rheum 49: 214-24.

11. Kucukdeveci AA, Sahin H, Ataman S, et al. (2004): Issues in cross-cultural validity: example from the adaptation reliability and validity testing of a Turkish version of the Stanford Health Assessment Questionnaire (HAQ). Arthritis Care Res 51: $14-19$

12. Andresen EM, Meyers AR (2000): Health-related quality of life outcomes measures. Arch Phys Med Rehabil 81: 30-45.

13. Aydin S (2015): A short history, principles, and types of ELISA, and our laboratory experience with peptide/protein analyses using ELISA. Peptides 72: 4-15.

14. Larsen A (1995): How to apply Larsen score in evaluating radiographs of rheumatoid arthritis in long-term studies. J Rheumatol 22: 1974-1975.

15. Katano M, Okamoto K, Arito M, et al. (2009): Implication of granulocyte-macrophage colony-stimulating factor induced neutrophil gelatinase-associated lipocalin in pathogenesis of 
rheumatoid arthritis revealed by proteome analysis Arthritis Res Ther 11: R3.

16. McInnes IB, Schett G (2007): Cytokines in the pathogenesis of rheumatoid arthritis. Nat Rev Immunol 7: 429-442.

17. Cowland JB, Borregaard N (1997): Molecular characterization and pattern of tissue expression of the gene for neutrophil gelatinase-associated lipocalin from humans. Genomics 1997; 45: $17-23$

18. Kjeldsen L, Bainton DF, Sengelov H, et al. (1994): Identification of neutrophil gelatinase-associated lipocalin as a novel matrix protein of specific granules in human neutrophils. Blood 83:799-807.

19. Li YN, Hu FL, Dai YJ, et al. (2014): Serum anti-lipocalin 2 $\mathrm{IgG}$ is a novel biomarker in the diagnosis of systemic lupus erythematosus. Lupus 23: 868-875. 